\title{
A multibiomarker approach in rats to assess the impact of pollution on Sinos River, southern Brazil
}

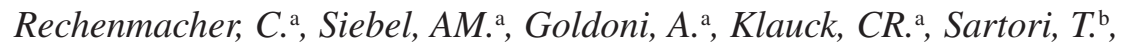 \\ Rodrigues, MT. ${ }^{\mathrm{b}}$, Rodrigues, MAS. ${ }^{\mathrm{c}}$, Gehlen, ${ }^{\mathrm{d}}{ }^{\mathrm{d}}$, Ardenghi, $P G .{ }^{\mathrm{e}}$ and Silva, LB. ${ }^{\mathrm{f} *}$ \\ ${ }^{a}$ Curso de Ciências Biológicas, Universidade Feevale, RS 239, 2755, CEP 93352-000, Novo Hamburgo, RS, Brazil \\ ${ }^{\text {bC }}$ urso de Biomedicina, Universidade Feevale, RS 239, 2755, CEP 93352-000, Novo Hamburgo, RS, Brazil \\ 'Programa de Pós-graduação em Qualidade Ambiental, Grupo de Pesquisa em Tecnologias Ambientais, \\ Universidade Feevale, RS 239, 2755, CEP 93352-000, Novo Hamburgo, RS, Brazil \\ ${ }^{\mathrm{d}}$ Grupo de Pesquisa em Indicadores de Qualidade Ambiental,Universidade Feevale, \\ RS 239, 2755, CEP 93352-000, Novo Hamburgo, RS, Brazil \\ ePrograma de Pós-graduação em Qualidade Ambiental, Grupo de Pesquisa Saúde Humana e Ambiente, \\ Universidade Feevale, RS 239, 2755, CEP 93352-000, Novo Hamburgo, RS, Brazil \\ fPrograma de Pós-graduação em Qualidade Ambiental, Grupo de Pesquisa em Indicadores de Qualidade Ambiental, \\ Universidade Feevale, RS 239, 2755, CEP 93352-000, Novo Hamburgo, RS, Brazil \\ *e-mail address: lucianosilva@feevale.br
}

Received February 21, 2010 - Accepted April 29, 2010 - Distributed December 31, 2010

(With 2 figures)

\begin{abstract}
The aim of this study was to determine the feasibility of combining water quality analysis with different biomarkers to characterise the relationship between anthropogenic contamination and biotic response in the Sinos River, southern Brazil. Wistar rats were studied using three biomarkers combined with physical, chemical and microbiological analysis to assess the effects of pollution at four sampling sites. The induction of oxidative stress was quantified by MDA levels in peripheral blood, lymphocyte DNA damage was determined using the comet assay, and histopathological changes were analysed in the liver. After sampling, animals were allowed to drink the river water during a 48 hours period. No increase in oxidative stress and DNA damage was observed. However, liver damage was observed in the animals exposed to water samples, indicating that the Sinos River is contaminated with hepatotoxic substances. Water analyses confirmed that water quality decreased downriver.
\end{abstract}

Keywords: genotoxicity, pollution, biomarkers, oxidative stress, tissue damage.

\section{Análise de múltiplos biomarcadores em ratos para determinar o impacto da poluição do rio dos Sinos}

\section{Resumo}

O objetivo deste estudo foi determinar a viabilidade de combinar a análise da qualidade da água com o estudo de biomarcadores para caracterizar a relação entre contaminação antropogênica e resposta biótica no rio dos Sinos, sul do Brasil. Ratos Wistar machos foram estudados usando três biomarcadores combinados com análises físicas, químicas e microbiológicas para determinar os efeitos da poluição em quatro locais de amostragem de água. A indução do estresse oxidativo foi quantificada pelos níveis de MDA no sangue periférico, o dano do DNA linfocitário foi determinado usando o ensaio cometa, e as alterações histopatológicas foram analisadas no fígado. As amostras da água do rio dos Sinos (dos quatro pontos selecionados) foram administradas por via oral (como água para beber) por 48 horas. Nenhum aumento do estresse oxidativo ou do dano do DNA foi observado. Entretanto, dano do tecido hepático foi verificado nos animais expostos à ingestão das amostras da água, indicando que o rio dos Sinos está contaminado com substâncias hepatotóxicas. As análises das amostras de água confirmaram a redução da qualidade da água em direção à foz do rio.

Palavras-chave: genotoxicidade, poluição, biomarcadores, estresse oxidativo, dano tecidual. 


\section{Introduction}

Surface waters, such as rivers, receive large quantities of wastewater from industrial, agricultural, and domestic sources, including municipal sewage treatment plants. Water pollution is known to be detrimental to human health and aquatic ecosystems, since surface waters are used both as a source of drinking water and for agricultural, recreational and religious activities around the world (Ohe et al., 2004).

Many pollutants (or their metabolites) may cause toxicity-related oxidative stress and DNA damage. Oxidative stress describes a condition in which cellular antioxidant defenses are insufficient to keep the levels of reactive oxygen species (ROS) below a toxic threshold (Schulz et al., 2000). Chronic oxidative stress due to exposure to environmental stressors might influence cellular physiology, leading to impairment of the fitness of individual organisms (Jha, 2008). Moreover, oxidative stress is accepted as a critical pathophysiological mechanism in several frequent human pathologies, including cancer (Mena et al., 2009).

A condition of oxidative stress can be revealed through searching for specific biomarkers of oxidative damage to lipids, proteins and nucleic acids (Migliore and Coppedè, 2009). The action of ROS on membrane lipids produces peroxides, such as malondialdehyde (MDA), which has been used as a marker of lipid peroxidation (Del Rio et al., 2005).

ROS have been associated with a number of tissue/ organ injuries induced by xenobiotics (Mena et al., 2009). In vertebrates, the liver plays a fundamental role in the biotransformation of xenobiotics, which involve both hepatocytes and Kupffer cells through enzymatic and nonenzymatic mechanisms. Therefore, the liver is the most appropriate organ to evaluate the responses of most environmental pollutants (Fenoglio et al., 2005). In general, biotransformation occurs in hepatocytes, through the activity of enzymes of the endoplasmic reticulum. Due to their respective catalase and superoxide dismutase (SOD) activity, peroxisomes and mitochondria are also involved at some stage of biotransformation. Furthermore, hepatocytes are protected against chemical injury by agents such as glutathione (GSH), which acts as a reducing agent and participates in the detoxification of xenobiotics and in the metabolism of numerous cellular compounds. Clinical chemistry and histopathological evaluations are commonly used methods for detecting organ-specific effects related to chemical exposure (Travlos et al., 1996; Crissman et al., 2004).

Studies to monitor contamination of surface waters have shown that some rivers in the world are contaminated with genotoxic chemicals (Ohe et al., 2004). The single-cell gel electrophoresis or comet assay is a rapid, sensitive and relatively inexpensive method to study DNA damage in different cell types. Comet assay plays an important role in genetic ecotoxicology to determine induced genetic damage, which has significant consequences for short- and long-term survival of the natural or wild species (Jha, 2008).
In vivo comet assay in rodents is an important test model for genotoxicity studies (Dhawan et al., 2009).

The subtropical Sinos River, located in Brazil's southernmost State, Rio Grande do Sul, is an example of an impacted watercourse, which provides drinking water for 1.2 million inhabitants and for one of the most important industrial centres in Brazil. The most densely populated urban areas include the cities of Novo Hamburgo $(255,945$ inhab.), Canoas (326,458 inhab.) and São Leopoldo (207,721 inhab.), which are located in the lower reaches of the river. Studies by the State Environmental Protection Agency (Fundação Estadual de Proteção Ambiental - FEPAM) revealed high loads of domestic and industrial sewage in the lower reaches of the Sinos River (FEPAM, 2009).

The field of biomarker research has developed as a response to the need for more sensitive indicators of sublethal ecological effects (Bickham et al., 2000). Since individual biomarkers cannot reflect an impairment of the organism's health conditions, the concurrent use of several biomarkers is important to minimize misinterpretation in cases of complex pollution situations (Flammarion et al., 2002; Pacheco and Santos, 2002). The aim of this study was to combine the use of biomarkers, devised to measure DNA damage, oxidative stress and tissue injuries, with water quality analysis to determine the effects of pollution in the Sinos River.

\section{Material and Methods}

Four sampling sites were selected in the upper (Site 1, Caraá, 29 43' 26' S and 50 16' 46" W), middle (Site 2, Parobé, 29 41' 05' S and 50 50' 52" W) and lower (Site 3, Novo Hamburgo, 29 $44^{\prime} 21^{\prime \prime} \mathrm{S}$ and $51^{\circ} 07^{\prime} 22^{\prime \prime} \mathrm{W}$; Site 4, Sapucaia do Sul, $29^{\circ} 47^{\prime} 53^{\prime \prime}$ S and $51^{\circ} 11^{\prime} 24^{\prime \prime}$ W ) reaches of the Sinos River (Figure 1). In sampling site 1 potential sources of pollution are small agricultural plantations and pig and cattle breeding farms. Agricultural activities are intense in sampling site 2 . In the region of sampling site 3, sanitary and industrial sewage and garbage are discharged into the river. The sources of pollution are agricultural pesticides and sanitary and industrial sewage in sampling site 4 .

In the four selected sites, water samples were collected in December 2008, the month which corresponds to spring in the southern hemisphere and exhibits hot and rainy conditions in Rio Grande do Sul State. The water samples were collected in plastic or glass bottles at about $10 \mathrm{~cm}$ below the surface. All collected water samples were refrigerated at $4{ }^{\circ} \mathrm{C}$, transported to the laboratory and analysed within 24 hours, as is required for the analysis of non-preserved samples according to APHA (1998). On the same day, the water samples were sent for the experiments in rats.

The following parameters were assessed, based on the Standard Methods for the Examination of Water and Wastewater (APHA, 1998): $\mathrm{pH}$, chemical oxygen demand (COD), conductivity, chlorides, hardness, total nitrogen, ammoniacal nitrogen, phosphorus, aluminum, 


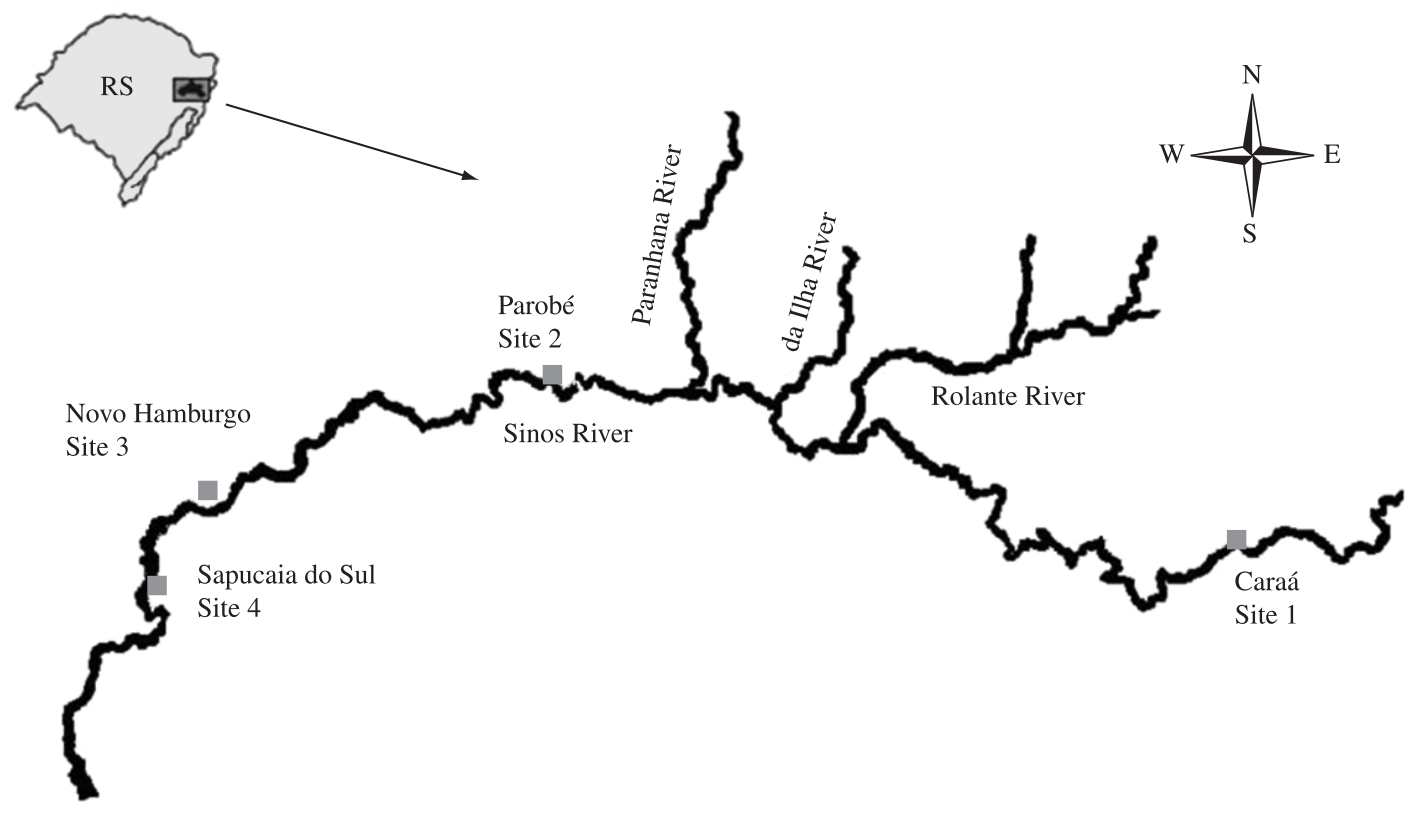

Figure 1. Location of the sampling sites (1,2,3, and 4) in the study area of the Sinos River basin, southern Brazil (Comitesinos, 2010).

lead, chromium, copper, nickel, iron, zinc, sodium, total solids, dissolved solids, total volatile solids, nitrite, nitrate, turbidity, dissolved oxygen (DO), total coliforms, and fecal coliforms (Escherichia coli).

Male albino Wistar rats, aged 2-3 months and weighing approximately 200-300 g, from our own breeding colony were used in the study. The animals were randomly divided into five groups: four treatment groups receiving water from four different sampling sites of the Sinos River (five animals per group) and one control group $(n=4)$.

Sinos River water samples were administered orally (as drinking water; Horst et al., 2010) for a 48 hours period to rats in the treatment groups. The control group received dechlorinated tap water. All animal groups were fed a standard laboratory diet, kept under the same temperature conditions $\left(25 \pm 1^{\circ} \mathrm{C}\right)$ and exposed daily to a 12-hours light/dark cycle. After 48 hours of treatment, the animals were killed by guillotine, a piece of the liver was collected for histological analysis and blood was collected into two tubes, $1 \mathrm{~mL}$ in one tube with sodium heparin, which was used for the assessment of DNA damage, and $4 \mathrm{~mL}$ in other tube with EDTA, for MDA analysis.

\subsection{Histopathological analysis}

Liver samples were obtained from all animals at surgery after euthanasia. A standard sample of $0.5 \mathrm{~cm}$ was always removed from the same hepatic lobe. All samples were fixed with $10 \%$ formaldehyde in phosphate-buffered saline for 24 hours. They were then washed with tap water, dehydrated in alcohol and embedded in paraffin. Sections of $8 \mu \mathrm{m}$ were mounted on saline-coated glass slides. Tissue was evaluated after hematoxylin-eosin staining.
At least two slides with 4 to 5 sections of each liver were examined under an Olympus microscope (Model CX 41) and recorded using a CCD camera (Olympus DSC 3000). An experienced histologist, blinded to treatment assignment, performed all histological assessments.

A semi-statistical analysis of the histopathological findings in the liver was performed, and the following symbols were used to describe the frequency (abundance) of structural changes: —_ absence of changes in animals within a group; ++++ , a change often found in all animals within a group; +++-, a change observed in almost all animals within a group; ++, a change not so often observed in all experimental animals within a group; - - , a change rarely observed within a group (Ishak et al., 1995).

\subsection{Malondialdehyde (MDA)}

Plasma MDA was measured using the technique described by Antunes et al. (2008), using high-performance liquid chromatography (HPLC). The chromatographer was composed of a system of pumps (LC-10AT), controller (SCL-10A), degasser (DGV-14A), column oven (CTO-10AS), autosampler (SIL-10AF), and a diode array detector (DAD) (SPD-M10A). After alkaline hydrolysis to separate MDA from plasma proteins, $100 \mu \mathrm{L}$ of plasma was centrifuged at $14,500 \mathrm{~g}$ and $4{ }^{\circ} \mathrm{C}$; the supernatant was derivatised with dinitrophenylhydrazine (DNPH). After resting for 30 minutes in the dark, $5 \mu \mathrm{L}$ of the sample was injected into the HPLC-DAD unit by means of isocratic elution at a flow rate of $1 \mathrm{~mL} / \mathrm{min}$. The column was kept at $30{ }^{\circ} \mathrm{C}$ during analysis. The Class VP 6.13 SP2 software (Kyoto, Japan) was used to control the system. Separation was achieved using a RP-18e Shim-Pack column $(150 \times 4.6 \mathrm{~mm}$ id, 
$5 \mu \mathrm{m})$, which was protected with a Shim-Pack G-ODS guard column ( $10 \times 4.0 \mathrm{~mm}$ id, $5 \mu \mathrm{m})$, both manufactured by Shimadzu (Kyoto, Japan). The absorption wavelength was set at $310 \mathrm{~nm}$, and DAD spectral acquisition at 200 to $380 \mathrm{~nm}$. At the same time, the calibration curve was obtained by adding standard solutions of MDA to samples of plasma to obtain concentrations of 1.5, 3.0, 5.0, 10.0, 20.0 , and $38.0 \mathrm{mM}$. All concentrations were analysed in six replicates, and the average of the six determinations was used to construct the calibration curve. The calibration curve was constructed by the correlation between the area obtained for MDA-DNPH chromatographic peak (y) and MDA concentrations added to plasma $(\mathrm{x})$. The calibration curve was analysed using the coefficient of determination (r2) and analysis of variance (ANOVA). The proposed method is sensitive, precise and accurate, and also uses experimental conditions that do not allow the generation of MDA during the test. It is a highly specific method, due to the use of a diode array detector, which enables the determination of the purity of chromatographic peaks.

\subsection{Comet assay}

The comet assay was performed according to Tice et al. (2000). Slides were prepared by adding $300 \mu \mathrm{L}$ of normal agarose solution to a frosted microscope slide, letting the agarose solidify (5-30 $\mathrm{min}$ at $4{ }^{\circ} \mathrm{C}$ ). A mixture of $5 \mu \mathrm{L}$ whole blood with $95 \mu \mathrm{L}$ low-melting-point agarose $(0.7 \%)$ was added to the slide; a coverslip was immediately added, and the slides were placed on a tray and kept in a refrigerator for $5 \mathrm{~min}$, until the agarose layer hardened. After that, the coverslip was gently slid off, and the slide was lowered into cold, freshly made lysing solution $(2.5 \mathrm{M}$ $\mathrm{NaCl}, 100 \mathrm{mM}$ EDTA, 10mM Tris, $\mathrm{pH} 10.2$, to which $1 \%$ Triton X-100 and 10\% DMSO had been added). After 1-24 hours at $4{ }^{\circ} \mathrm{C}$, the slides were gently removed from the lysing solution, and the excess liquid was blotted away from the back and edges. The slides were placed on the horizontal gel box at $4{ }^{\circ} \mathrm{C}$, which was filled with fresh electrophoresis buffer ( $300 \mathrm{mM} \mathrm{NaOH}, 1 \mathrm{mM}$ EDTA, $\mathrm{pH}>13$ ) until the liquid completely covered the slides. The slides were then left on the tray for 20 min before the power was turned on. Electrophoresis was performed at $25 \mathrm{~V}$ and $300 \mathrm{~mA}(\sim 0.95 \mathrm{~V} / \mathrm{cm})$ for $20 \mathrm{~min}$. The steps above were carried out under red light to avoid induction of DNA damage. After electrophoresis, the slides were gently removed from the tank, and neutralizing buffer (0.4 M Tris, $\mathrm{pH}$ 7.5) was added to the slides drop-wise three times, allowing the slides to sit for 5 min each time. The slides were rinsed three times in distilled water, air dried for at least 24 hours, and then fixed and silver stained according to Nadin et al. (2001). For evaluation of DNA damage, 100 cells per individual were analyzed under an optical microscope at 400x magnification. Cells were scored visually into five categories corresponding to the tail length: from undamaged (Type 0) to complete damage (Type IV) (Anderson et al., 1994). Based on the arbitrary values assigned to the different categories (from Type $0=$ 0 to Type IV $=4$ ), a genetic damage index was calculated
$[($ No. of Type 0 cells $\times 0)+($ No. of Type I cells $\times 1)+$ $($ No. of Type II cells $\times 2)+($ No. of Type III cells $\times 3)+$ (No. of Type IV cells $\times 4$ )] for each rat (Pitarque et al., 1999). Therefore, the total score per individual ranged from 0 (all undamaged) to 400 (all maximally damaged).

Statistical analysis on MDA and comet assay was performed using ANOVA. All analyses were carried out using the Statistical Package for the Social Sciences (SPSS) 15.0 for Windows, considering a significance level of $\mathrm{p} \leq 0.05$.

\section{Results}

The parameters of water samples collected at each sampling site in the Sinos River are described in Table 1. The National Environment Council (CONAMA - resolution 357/2005) establishes the standards for the water quality of freshwater resources. Recommended maximum levels of these parameters for water Class 1 are also shown in Table1. In general, the values of the investigated parameters increased from site 1 (source) toward site 4 (mouth). The presence of fecal coliforms indicates contamination either by fecal material of warm-blooded animals or sewage. Sampling sites 2, 3 and 4 showed fecal coliform content higher than water quality standards, which should be at a maximum of $200 \mathrm{NMP} / 100 \mathrm{~mL}$ according to Brazilian legislation (Brasil, 2005). Dissolved oxygen (DO) concentration in the analysed sites decreased downriver. The highest DO concentration was observed at site $1(8.24 \mathrm{mg} / \mathrm{L})$, and a reduction in DO concentration was observed at sites 2 and 3, 6.28 and $6.08 \mathrm{mg} / \mathrm{L}$, respectively. At sampling site 4, DO levels decreased significantly $(4.12 \mathrm{mg} / \mathrm{L})$, showing value below the minimum established ( $\geq 6.0 \mathrm{mg} / \mathrm{L})$. Maximum values for lead, chromium, copper, nickel, and zinc at the four sampling sites did not exceed the limits set out by CONAMA (Brasil, 2005). In the water samples of sites 2, 3 and 4, concentrations higher than permissive values established by the Brazilian legislation for Aluminum and Iron were observed.

Histological observations of the liver lobule were performed for the presence of pathological lesions. In the control group, the liver tissue sections examined, under light microscopy, were within the normal range. In the animals exposed to water from different sampling sites, liver sections displayed parenchymatous cells with cytoplasmic vacuolisation and, in some animals, degenerated nuclei. Liver damage was mild, the highest frequency of damage being observed in groups 1 and 2 . It is noteworthy that the type of tissue damage observed was the same in all groups treated with river water, only the frequency of occurrence varied (Table 2, Figure 2).

The results obtained by the comet assay in blood lymphocytes of rats exposed to Sinos River water samples are shown in Table 3. Damage index showed no statistically significant difference between exposed and control groups $(\mathrm{p}=0.79)$. The frequency of cells with DNA damage was very low: considering the total sample of animals, only about $5 \%$ of cells were scored into categories I to IV of 
Table 1. Physical, chemical and microbiological parameters of water samples collected at four different sites in the Sinos River in December/2008.

\begin{tabular}{|c|c|c|c|c|c|c|}
\hline Parameters & & Site 1 & Site 2 & Site 3 & Site 4 & Legislation $^{\mathrm{a}}$ \\
\hline 01. COD & $\mathrm{mgO} 2 \mathrm{~L}^{-1}$ & 2.0 & 6.0 & 10.0 & 13.0 & - \\
\hline 02. Chlorides & $\mathrm{mg} \mathrm{L}^{-1}$ & 1.4 & 0.8 & 3.6 & 4.6 & 250.0 \\
\hline 03. Conductivity & $\mu \mathrm{S} \mathrm{L}^{-1}$ & 31.65 & 57.75 & 87.95 & 94.4 & - \\
\hline 04. Hardness & $\operatorname{mgCaCO} 3 \mathrm{~L}^{-1}$ & 7.0 & 19.0 & 24.0 & 23.0 & - \\
\hline 05. Total nitrogen & $\mathrm{mg} \mathrm{L}^{-1}$ & 0.67 & 1.05 & 2.10 & 2.55 & - \\
\hline 06. Ammoniacal nitrogen & $\mathrm{mg} \mathrm{L}^{-1}$ & $<0.5$ & $<0.5$ & $<0.5$ & 1.65 & 3.7 \\
\hline 07. Total phosphorus & $\mathrm{mg} \mathrm{L}^{-1}$ & n.d. & n.d. & 0.146 & 0.12 & 0.1 \\
\hline 08. Aluminum & $\operatorname{mg~L} \mathrm{L}^{-1}$ & 0.07 & 0.7 & 1.02 & 1.30 & 0.1 \\
\hline 09. Lead & $\mathrm{mg} \mathrm{L}^{-1}$ & n.d. & n.d. & n.d. & n.d & 0.01 \\
\hline 10. Chromium & $\mathrm{mg} \mathrm{L}^{-1}$ & n.d. & n.d. & n.d. & n.d & 0.05 \\
\hline 11. Copper & $\mathrm{mg} \mathrm{L}^{-1}$ & 0.002 & 0.003 & 0.005 & 0.009 & 0.009 \\
\hline 12. Nickel & $\mathrm{mg} \mathrm{L}^{-1}$ & n.d. & n.d. & n.d. & n.d & 0.025 \\
\hline 13. Iron & $m g L^{-1}$ & 0.05 & 0.98 & 1.45 & 2.21 & 0.3 \\
\hline 14. Zinc & $\mathrm{mg} \mathrm{L}^{-1}$ & 0.01 & 0.01 & 0.10 & 0.04 & 0.18 \\
\hline 15. Sodium & $\mathrm{mg} \mathrm{L}^{-1}$ & 2.8 & 5.65 & 7.45 & 8.1 & - \\
\hline 16. Dissolved solids & $\operatorname{mg~L}{ }^{-1}$ & 20.0 & 135.0 & 96.0 & 97.0 & 500.0 \\
\hline 17. Total solids & $\mathrm{mg} \mathrm{L}^{-1}$ & 137.0 & 185.0 & 169.0 & 161.0 & - \\
\hline 18. Total volatile solids & $\mathrm{mg} \mathrm{L}^{-1}$ & 88.0 & 102.0 & 76.0 & 76.0 & - \\
\hline 19. $\mathrm{pH}$ & - & 6.98 & 7.05 & 6.92 & 6.89 & $6.0-9.0$ \\
\hline 20. Nitrate & $m g L^{-1}$ & 2.13 & 2.99 & 4.07 & 5.41 & 10.0 \\
\hline 21. Nitrite & $\mathrm{mg} \mathrm{L}^{-1}$ & n.d. & 0.006 & 0.03 & 0.07 & 1.0 \\
\hline 22. Turbidity & NTU & 0.02 & 12.4 & 18.4 & 31.6 & 40.0 \\
\hline 23. Dissolved oxygen & $\mathrm{mg} \mathrm{L}^{-1}$ & 8.24 & 6.28 & 6.08 & 4.12 & $\geq 6.0$ \\
\hline 23. Total coliforms & $\mathrm{NMP} / 100 \mathrm{~mL}$ & 629 & $23.3 \times 10^{3}$ & $13.5 \times 10^{3}$ & $714.8 \times 10^{3}$ & - \\
\hline $\begin{array}{l}\text { 24. Fecal coliforms } \\
\text { (Escherichia coli) }\end{array}$ & $\mathrm{NMP} / 100 \mathrm{~mL}$ & 41.0 & $7.3 \times 10^{3}$ & $4.1 \times 10^{3}$ & $3.2 \times 10^{3}$ & 200 \\
\hline
\end{tabular}

$\mathrm{COD}=$ chemical oxygen demand; n.d. = Not detected by the method. ${ }^{\mathrm{a}}$ Maximum values allowed by Brazilian legislation — resolution 357/2005 of the National Environment Council (CONAMA) for water Class 1.

Table 2. Histopathological findings in the liver of rats exposed to water from four sampling sites in the Sinos River.

\begin{tabular}{lccccc}
\hline \multicolumn{1}{c}{ Findings } & Control & Site 1 & Site 2 & Site 3 & Site 4 \\
\hline Nucleus fragmentation & - & ++ & -+ & -+ & -+ \\
Mononuclear cell infiltrations & - & -+ & ++- & -+ & ++- \\
Cytoplasmic vacuolization & - & ++++ & +++- & ++- & -+ \\
\hline
\end{tabular}

- absence of changes in experimental animals within a group; ++++, a change often found in all experimental animals within a group; +++-, a change found in almost all experimental animals within a group; ++-, a change not so often found in all experimental animals within a group; -+, a change rarely found within a group.

damage. A comparison of plasma MDA levels did not reveal any significant differences between exposed and control groups ( $\mathrm{p}=0.85$, Table 3$)$.

\section{Discussion}

Given the concern about the environmental consequences of pollution, several approaches have been proposed for the assessment and prediction of effects of pollutants. Data obtained through studies using simultaneous application of multiple biomarkers could provide a broader dimension of the toxicological impact of environmental contaminants on the test organism.

Water quality is generally assessed by the analysis of physical, chemical and biological parameters. Overall, water quality parameters showed that the Sinos River is highly polluted. Dissolved oxygen was significantly lower downstream, and other water parameters, such as fecal coliforms and ammoniacal nitrogen, increased toward the mouth of the river. Poor water quality found in the lower reaches of the Sinos River results directly from agricultural, livestock and industrial wastewater, and also 

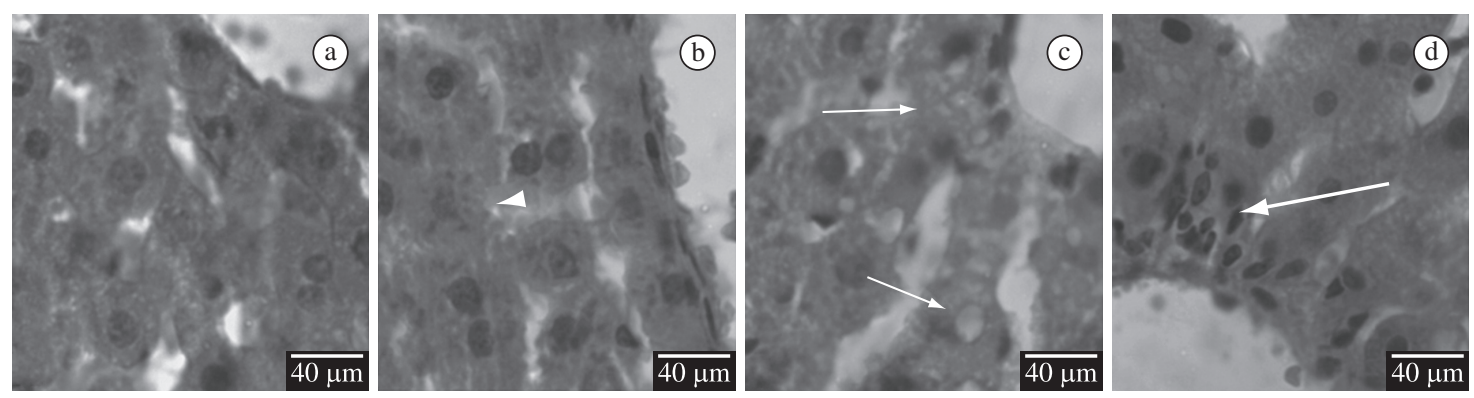

Figure 2. Liver tissue sections; a) control animals showing normal hepatocytes and their round nucleus; b) animal from site 1 with nuclear fragmentation (arrow head); c) animal from site 2 showing parenchymatous cells with cytoplasmic vacuolization of different sizes (thin arrows); and d) animal from site 4 showing small area with cell infiltration (arrow). All sections used H\&E stain.

Table 3. Effects of exposure to Sinos River water samples on MDA level $(\mu \mathrm{M})$, and damage index of comet assay in peripheral blood of rats.

\begin{tabular}{cccc}
\hline Sample & N & $\begin{array}{c}\text { Comet assay } \\
\text { Damage index }\end{array}$ & MDA \\
\hline Control group & 4 & $6.3 \pm 2.2$ & $3.4 \pm 0.6$ \\
Sampling site 1 & 5 & $8.4 \pm 5.7$ & $3.2 \pm 0.6$ \\
Sampling site 2 & 5 & $9.2 \pm 4.7$ & $3.7 \pm 0.2$ \\
Sampling site 3 & 5 & $7.6 \pm 5.9$ & $3.5 \pm 1.1$ \\
Sampling site 4 & 5 & $6.0 \pm 3.4$ & $3.3 \pm 0.9$ \\
p & & 0.79 & 0.85 \\
\hline
\end{tabular}

MDA = malondialdehyde. $\mathrm{N}=$ number of animals. Damage index in 100 cells/animal [(No. of Type 0 cells $x$ 0) $+($ No. of Type I cells x 1) + (No. of Type II cells x 2) + (No. of Type III cells x 3) + (No. of Type IV cells x 4)].

as a consequence of a high population density, which is associated with the release of raw, untreated sewage. The discharge of organic matter into river waters leads to a decrease in the level of dissolved oxygen, which is one of the most important parameters available in the field of water pollution control, as it allows an evaluation of the aerobic conditions in a watercourse receiving pollutant discharges (Jordão et al., 2007). Studies by the State Environmental Protection Agency (Fundação Estadual de Proteção Ambiental - FEPAM) showed high loads of domestic and industrial sewage in the lower reaches of the Sinos River (FEPAM, 2009), where the sampling sites 3 and 4 of the present study were located.

Free-radical mechanisms are well known to cause lipid peroxidation (Marnett, 1999). We used a naturally occurring product of lipid peroxidation, plasma malondialdehyde (MDA) levels, as an indicator of oxidative stress. The treatment of rats over a 48 hours period with water samples from the Sinos River did not reveal an increase in lipid peroxidation. Since MDA is able to form DNA adducts and to cause oxidative DNA damage, we investigated DNA damage using the comet assay. The comet assay has been used by many research groups in environmental biomonitoring studies, as it is a simple, sensitive and broad-specificity tool (Jha, 2008). In the present study, no genotoxic effects were observed after exposure to Sinos
River water samples, a result that agrees with the absence of oxidative stress. However, it is important to highlight the need to evaluate genotoxicity and oxidative stress with different experimental design, regarding water administration and exposure time, to provide a broader dimension of the toxicological effects of Sinos River on rats.

Histopathology of the major organs involved in metabolism and excretion of xenobiotics, as the liver, are useful biomarkers of the effects of pollution (Koyu et al., 2006). Several studies have reported that oxidative stress plays a central role in disease pathogenesis and in tissue damage in response to toxicant exposures (Roberts et al., 2009). For example, Koyu et al. (2006) showed that cadmium has an important toxic effect on liver tissue and concluded that cadmium exhibits its toxicity by increasing lipid peroxidation. Tabrez and Ahmad (2009) evaluated antioxidant enzymes and MDA levels of rats treated with polluted water collected from industrial regions of the urban area of India. The results revealed kidney and liver damage and increased MDA with suppression of the antioxidant system, suggesting that polluted water causes significant oxidative stress. In the present study, all treatment groups showed mild liver damage, and the presence of parenchymatous cells with cytoplasmic vacuolization and degenerated nuclei, in the hepatocytes of the exposed animals, suggests the presence of hepatotoxic 
substances in the Sinos River. Most data concerning the toxic effects of pollutants on the structure and function of organs come from experiments in laboratory animals exposed to a single compound, such as heavy metals (Damek-Poprawa and Sawicka-Kapusta, 2004; Koyu et al., 2006), and less frequently to complex mixtures, such as rivers. Contaminated rivers often contain a wide variety of organic and inorganic pollutants, including potentially toxic metals such as $\mathrm{Pb}, \mathrm{Cd}, \mathrm{Fe}, \mathrm{Zn}, \mathrm{Cu}, \mathrm{Mn}, \mathrm{Mo}$, and Cr (Sánchez-Chardi et al., 2007). Oxidative stress may be attributed to these elements, producing a variety of alterations in tissues (Jadhav et al., 2007 ). However, tissue damage can occur by means of several mechanisms and our findings suggest that the liver damage observed in the exposed animals was not related to lipid peroxidation, since no increase in MDA levels was observed.

The incorporation of ecologically relevant biomarkers into routine environmental management programs has been advocated as a pragmatic means of linking environmental degradation with its causes (Galloway et al., 2004). Humans, aquatic life and other living organisms are constantly exposed to contaminants from factories, refineries, sewage treatment plants, fertilizers and pesticides washed into rivers, or urban water supplies. Therefore, the assessment of the effects of contaminated water on the liver, kidney and colon of rats is of great importance for a possible prediction of such effects on humans. Human exposure to contaminated water, at high levels, may result in damage to several tissues, leading to death at excessive levels. At low levels, heme synthesis and other biochemical processes, such as bilirubin and albumin, may be affected, and psychological and neurobehavioral functions may be impaired, as well as a wide range of other effects (Adeyemi et al., 2009).

The use of a group of biomarkers covering different levels of biological organization provides knowledge about at what level pollutants interact with the body and at what level the body is more susceptible to the action of pollutants. The results of studies such as the present one are essential to the design of effective strategies targeting the rehabilitation of biodiversity in aquatic ecosystems.

Acknowledgements - This study was supported in part by a research grant from Conselho Nacional de Desenvolvimento Científico e Tecnológico (CNPq - number 477192/2007-6) and by a Student Fellowship from the Fundação de Amparo à Pesquisa do Estado do Rio Grande do Sul (FAPERGS) granted to an undergraduate student (CR).

\section{References}

ADEYEMI, O., AJAYI, JO., OLAJUYIN, AM., OLOYEDE, OB., OLADIJI, AT., OLUBA, OM., OLOLADE, IA. and ADEBAYO, EA., 2009. Toxicological evaluation of the effect of water contaminated with lead, phenol and benzene on liver, kidney and colon of Albino rats. Food and Chemical Toxicology, vol. 47, no. 4 , p. $885-887$.

American Public Health Association - APHA, 1998. Standard Methods for the Examination of Water and Wastewater. $20^{\text {th }}$ ed. Washington, D.C.: APHA/AWWA/WPCF.
ANDERSON, D., YU, TW., PHILLIPS, BJ. and SCHEZER, P., 1994. The effect of various antioxidants and other modifying agents on oxygen-radical generated DNA damage in human lymphocytes in the comet assay. Mutation Research, vol. 307, p. 261-271.

ANTUNES, MV., LAZARETTI, C., GAMARO, GD. and LINDEN, R., 2008. Estudo pré-analítico e de validação para determinação de malondialdeído em plasma humano por cromatografia líquida de alta eficiência, após derivatização com 2,4 dinitrofenilhidrazina. Revista Brasileira Ciências Farmacêuticas, vol. 44, p. 279-287.

BICKHAM, JW., SANDHU, S., HEBERT, PD., CHIKHI, L., ATHWAL, R., 2000. Effects of chemical contaminants on genetic diversity in natural populations: implications for biomonitoring and ecotoxicology. Mutation Research, vol. 463, p. 33-51.

Brasil. Conselho Nacional do Meio Ambiente - CONAMA, 2005. Resolução n. 357/2005. Dispõe sobre a classificação dos corpos de água e diretrizes ambientais para o seu enquadramento, bem como estabelece as condições e padrões de lançamento de efluentes, e dá outras providências. Diário Oficial da União, Brasília, DF, 18 mar. 2005.

CRISSMAN, JW., GOODMAN, DG., HILDEBRANDT, PK., MARONPOT, RR., PRATER, DA., RILEY, JH., SEAMAN, WJ. and THAKE, DC., 2004. Best practice guideline: toxicologic histopathology. Toxicologic Pathology, vol. 32, p. 126-31.

DAMEK-POPRAWA, M. and SAWICKA-KAPUSTA, K., 2004. Histopathological changes in the liver, kidneys, and testes of bank voles environmentally exposed to heavy metal emissions from the steelworks and zinc smelter in Poland. Environmental Research, vol. 96, p. 72-78.

DEL RIO, D., STEWART, AJ. and PELLEGRINI, N., 2005. A review of recent studies on malondialdehyde as toxic molecule and biological marker of oxidative stress. Nutrition, Metabolism \& Cardiovascular Diseases, vol. 15, p. 316-328.

DHAWAN, A., BAJPAYEE, M. and PARMAR, D., 2009. Comet assay: a reliable tool for the assessment of DNA damage in different models. Cell Biology and Toxicology, vol. 25, p. 5-32.

FENOGLIO, C., BONCOMPAGNI, E., FASOLA, M., GANDINI, C., COMIZZOLI, S., MILANESI, G. and BARNI, S., 2005. Effects of environmental pollution on the liver parenchymal cells and Kupffer-melanomacrophagic cells of the frog Rana esculenta. Ecotoxicology and Environmental Safety, vol. 60, p. 259-268.

FLAMMARION, P., DEVAUX, A., NEHLS, S., MIGEON, B., NOURY, P. and GARRIC, J., 2002. Multibiomarker responses in fish from the Moselle River (France). Ecotoxicology and Environmental Safety, vol. 51, p. 145-153.

Fundação Estadual de Proteção Ambiental Henrique Luiz Roessler - FEPAM, 2009. Qualidade das águas da bacia hidrográfica do rio dos sinos. Available from: <http://www.fepam.rs.gov.br/ qualidade/qualidade_sinos $>$.

GALLOWAY, TS., BROWN, RJ., BROWNE, MA., DISSANAYAKE, A., LOWE, D., JONES, MB. and DEPLEDGE, MH., 2004. A multibiomarker approach to environmental assessment. Environmental Science \& Technology, vol. 38, no. 6, p. 1723-1731.

HORST, MA., ONG, TP., JORDÃO Jr., AA., VANNUCCHI, H., MORENO, FS. and LAJOLO, FM., 2010. Water extracts of cabbage and kale inhibit ex vivo H2O2-induced DNA damage but not rat hepatocarcinogenesis. Brazilian Journal of Medical and Biological Research, vol. 43, p. 242-248. 
ISHAK, K., BAPTISTA, A., BIANCHI, L., CALLEA, F., DE, G., GUDAT, F., DENK, H., DESMET, V., KORB, G. and MACSWEEN, RN., 1995. Histological grading and staging of chronic hepatitis. Journal of Hepatology, vol. 22, p. 696-699.

JADHAV, SH., SARKAR, SN., PATIL, RD. and TRIPATHI, HC., 2007. Effects of subchronic exposure via drinking water to a mixture of eight water-contaminating metals: a biochemical and histopathological study in male rats. Archives Environmental Contamination and Toxicology, vol. 53, p. 667-677.

JHA, AN., 2008. Ecotoxicological applications and significance of the comet assay. Mutagenesis, vol. 23, no. 3, p. 207-221.

JORDÃO, CP., RIBEIRO, PRS., MATOS, AT. and FERNANDES, RBA., 2007. Aquatic Contamination of the Turvo Limpo River Basin at the Minas Gerais State, Brazil. Journal of the Brazilian Chemical Society, vol. 18, no. 1, p. 116-125.

KOYU, A., GOKCIMEN, A., OZGUNER, F., BAYRAM, DS. and KOCAK, A., 2006. Evaluation of the effects of cadmium on rat liver. Molecular and Cellular Biochemistry, vol. 284, no. 1-2, p. 81-85.

MARNETT, LJ., 1999. Lipid peroxidation-DNA damage by malondialdehyde. Mutation Research, vol. 424, p. 83-95.

MENA, S., ORTEGA, A. and ESTRELA, JM., 2009. Oxidative stress in environmental-induced carcinogenesis. Mutation Research, vol. 674 , no. $1-2$, p. $36-44$.

MIGLIORE, L. and COPPEDÈ, F., 2009. Environmental-induced oxidative stress in neurodegenerative disorders and aging. Mutation Research, vol. 674, no. 1-2, p. 73-84.

NADIN, SB., VARGAS-ROIG, LM. and CIOCCA, D., 2001. A silver staining method for single-cell gel assay. Journal of the Histochemical Society, vol. 49, p. 1183-1186.

OHE, T., WATANABE, T. and WAKABAYASHI, K., 2004. Mutagens in surface waters: a review. Mutation Research, vol. 567, p. 109-149.
PACHECO, M. and SANTOS, MA., 2002. Biotransformation, genotoxic, and histopathological effects of environmental contaminants in European eel (Anguilla anguilla L.). Ecotoxicology and Environmental Safety, vol. 53, p. 331-347.

PITARQUE, M., CREUS, A., MARCOS, R., HUGHES, JA. and ANDERSON, D., 1999. Examination of various biomarkers measuring genotoxic endpoints from Barcelona airport personnel. Mutation Research, vol. 440, p. 195-204.

ROBERTS, RA., LASKIN, DL., SMITH, CV., ROBERTSON, FM., ALLEN, EMG., DOORN, JA. and SLIKKERK, W., 2009. Nitrative and Oxidative Stress in Toxicology and Disease. Toxicological Science, vol. 112, no. 1, p. 4-16.

SÁNCHEZ-CHARDI, A., PEÑARROJA-MATUTANO, C., RIBEIRO, CAO. and NADAL, J., 2007. Bioaccumulation of metals and effects of a landfill in small mammals. Part II. The wood mouse Apodemus sylvaticus. Chemosphere, vol. 70, p. 101-109.

SCHULZ, JB., LINDENAU, J., SEYFRIED, J. and DICHGANS, J., 2000. Glutathione, oxidative stress and neurodegeneration. European Journal of Biochemistry. vol. 267, p. 4904-4911.

TABREZ, S. and AHMAD, M., 2009. Effect of wastewater intake on antioxidant and marker enzymes of tissue damage in rat tissues: Implications for the use of biochemical markers. Food and Chemical Toxicology, vol. 47, p. 2465-2478.

TICE, RR., AGURELL, E., ANDERSON, D., BURLINSON, B., HARTMANN, A., KOBAYASHI, H., MIYAMAE, Y., ROJAS, E., RYU, JC. and SASAKI, YF., 2000. Single cell gel/comet assay: guidelines for in vitro and in vivo genetic toxicology testing. Environmental and Molecular Mutagenesis, vol. 35, p. 206-221.

TRAVLOS, GS., MORRIS, RW., ELWELL, MR., DUKE, A., ROSENBLUM, S. and THOMPSON, MB., 1996. Frequency and relationship of clinical chemistry and liver and kidney histopathology findings in 13-week toxicity studies in rats. Toxicology, vol. 107, p. 17-29. 